\title{
EFFECT OF HYDROGEL AND DIFFERENT TYPES OF FERTILIZERS ON THE NUMBER OF TURF SHOOTS IN LAWNS CREATED BY MONOCULTURES OF RED FESCUE (Festuca rubra L.) CULTIVARS AND ITS MIXTURES
}

\author{
Kazimierz Jankowski, Jacek Sosnowski, Jolanta Jankowska \\ Department of Grassland and Green Areas Creation, University of Natural Sciences and Humanities in Siedlce \\ 08 -110 Siedlce, B. Prusa 14, Poland, e-mail: laki@uph.edu.pl
}

Received: 22.01.2011

\begin{abstract}
In order to determine the effect of the hydrogel content in the soil substrate on the number of shoots per unit area of grass lawns with different proportions of red fescue and monoculture turf produced from the following fescue cultivars: Adio, Libano, Corail, Simone. In the period 2003-2004, a field experiment was carried out in a randomized block design in four replications. In combination with a hydrogel (Aqua-Gel P4), $0.05 \mathrm{~kg} \times \mathrm{m}^{-2}$ of sorbent was placed at a depth of $10 \mathrm{~cm}$ below the soil surface in 2002. Another experimental factor was the type of fertilizer. Trawovit (a fertilizer with standard effects) and Sierrablen (a controlled-release fertilizer) were used for this purpose. The quantities of fertilizer and time of fertilization date followed manufacturer's instructions. The number of shoots per $1 \mathrm{~m}^{2}$ was determined at the end of the growing season. The study showed that, regardless of years of cultivation, the type of soil substrate and fertilizer, the average number of shoots for the mixtures was about $32 \%$ lower than for monoculture lawns. The presence of the hydrogel in the soil substrate regulated soil moisture, and therefore in the mixture lawns the values of the tested features were significantly higher in the treatments with hydrogel. Fertilization with Trawovit, regardless of the type of soil substrate $(\mathrm{H}, \mathrm{BH})$, does not lead to a statistically significant difference in the number of shoots between the studied mixtures. However, in the treatments fertilized with Sierrablen, the presence of the hydrogel in the soil substrate caused a significant increase in the traits examined for the mixtures containing, respectively, 20 and $80 \%$ of red fescue in their composition. The addition of Aqua-Gel P4 to the soil substrate, when the turf lawns were fertilized with Trawovit, resulted in a significant increase in the number of shoots for the cultivars Adio, Libano and Corail.
\end{abstract}

Key words: shoots, hydrogel, lawn grass, red fescue

\section{INTRODUCTION}

Recently, more and more importance has given to red fescue as an important component of lawns
(M a rtyniak, 2006), used both to establish decorative lawns and sports lawns (Rutkowska and He m pe l, 1996) as well as to obtain compactness of soil surface on scarps, slopes and in derelict land (Kitczak and Czyż, 2009). A study of red fescue conducted by Martyniak (2005) claims that its reproduction is highly dependent on plant density per area unit, emergence, installation of plants and, consequently, on the number of shoots and density of the lawn. In turn, Domański (2002) argues that the most important criterion in assessing suitability of species and varieties of lawn grasses is the coverage of the ground by shoots. He believes that in the years of complete cultivation the degree of coverage is subject to variation and is dependent on the season and on weather conditions. In addition, he draws attention to the dynamics of tillering, directly affecting the overall aspect of the turf.

W ols ki et al. (2006) thinks that the most critical moment is the period of initial growth of plants forming turf and underlines the efficiency of acrylic polymer (hydrogel), which contributes to the development of the root system and green mass, offsetting the impact of unsuitable weather conditions. According to L e c i e j e w s ki (2008), the hydrogel addition significantly affected the increase of soil moisture and slowed the loss of water at all depths of the studied soil profile. These observations are confirmed by the results presented in another paper (Martyn and Onuch- Amborska, 1998) which show that the drying rate of greenhouse substrates depends on the proportion of the sorbent. Thus, the sorbent is characterized by high water sorption capacity, increasing water capacity of the soil. This effect may be associated with the interruption of vertical pores in the soil, which reduces evaporation of water, while maintaining soil porosity $(\mathrm{Me} 11 \mathrm{ou} 1 \mathrm{i}$ et 
al. 1998). Moreover, according to P o g r o s z e w s k a (1998) and A l- H a r b i et al. (1999), hydrogel reduces the density of the soil substrate, which contributes to the increase of soil loosening. Soils with higher concentrations of hydrogel dry slower when their moisture content in the initial period is lower. After some time, they have higher moisture content than soil without hydrophilic polymers. Therefore, the aim of this work was to determine the effect of hydrogel placed in the subsoil and of the type of fertilization on the number of shoots per unit area of lawns planted using monocultures and mixtures with varying proportions of red fescue.

\section{MATERIALS AND METHODS}

The study was carried out on the basis of two lawn experiments that were set up in a randomized block design in four replications in 2002. The experimental unit was a plot with an area of $1 \mathrm{~m}^{2}$. The soil substrate used in the experiments belongs to the soil classified as anthropogenic soils (Table 1).

On the basis of soil chemical analysis done at the Chemical Agriculture Station, it was found that the soil from the studied cultivations was characterized by a neutral reaction - in $\mathrm{KCl}$ (Table 2). According to Kowaliński and Gonet (1999), the level of humus in Polish soils ranges from 0.6 to $6.0 \%$. On this basis, it can be concluded that in the tested soil the humus content was at a medium-high level. Furthermore, it is characterized by a very high content of phosphorus, a high content of magnesium, and an average content of available forms of potassium, total nitrogen, nitrate, and ammonium (G r z e b i s z , 2009).

Meteorological data for 2002-2004 were obtained from the Hydrological - Meteorological Station. In order to determine the temporal and spatial variability of meteorological elements and to assess their influence on the plant growth rate, was calculated Selyaninov's hydrothermal coefficient - K (B a c, 1993), by dividing total monthly rainfall by one-tenth of the sum of average daily temperatures for a given month.

For the study purposes, lawn types were distinguished and called a monoculture lawn (pure sowing) or a mixed lawn (Table 4). Four cultivars of red fescue (Festuca rubra): Adio, Libano, Corail, Simone, were studied in the monoculture treatment. In the mixed lawns, one of the experimental factors was the proportion of red fescue in the grass mixture.

Table 1

The grain composition of soil used as a soil substrate in the experiment

\begin{tabular}{ccccccccc}
\hline \multicolumn{8}{c}{ Percentage proportion of soil fractions (diameter in mm) } \\
\hline $1-0.1$ & $0.1-0.05$ & $0.05-0.02$ & $0.02-0.06$ & $\begin{array}{c}0.06- \\
0.002\end{array}$ & $<0.002$ & $\begin{array}{c}\text { Sum of fraction } \\
0.1-0.02\end{array}$ & $\begin{array}{c}\text { Sum of fraction } \\
<0.02\end{array}$ & Grain group \\
\hline 76 & 9 & 5 & 4 & 4 & 2 & 14 & 10 & Psg swe \\
\hline
\end{tabular}

Table 2

The chemical composition of used as a soil substrate in the experiment

\begin{tabular}{cccccccc}
\hline $\mathrm{pH}$ & \multicolumn{3}{c}{$\begin{array}{c}\text { Content of available elements } \\
\text { in } \mathrm{mg} \times 100 \mathrm{~g}^{-1} \text { of soil }\end{array}$} & & Content in $\%$ & & $\begin{array}{c}\text { Content } \\
\mathrm{mg} \times \mathrm{kg}^{-1} \mathrm{DM}\end{array}$ \\
\hline in $\mathrm{KCl}$ & $\mathrm{P}_{2} \mathrm{O}_{5}$ & $\mathrm{~K}_{2} \mathrm{O}$ & $\mathrm{Mg}$ & $\mathrm{N}-$ total & Humus & $\mathrm{N}^{-\mathrm{NO}_{3}}$ & - \\
\hline 6.99 & 90.0 & 19.0 & 8.4 & 0.18 & 3.78 & 10.10 & 7.47 \\
\hline $\pm 3 \%$ & $\pm 20 \%$ & $\pm 20 \%$ & $\pm 20 \%$ & $\pm 20 \%$ & $\pm 17 \%$ & $\pm 22 \%$ & $\pm 25 \%$ \\
\hline
\end{tabular}

* Expanded uncertainty calculated by using of the expanded index 2, which gives a level of $95 \%$

Table 3

Selyaninov's hydrothermal coefficients in individual months of the 2003-2004 growing seasons

\begin{tabular}{ccccccccc}
\hline \multirow{2}{*}{ Study years } & \multicolumn{9}{c}{ Month } \\
\cline { 2 - 8 } & IV & V & VI & VII & VIII & IX & X \\
\hline 2003 & 1.30 & 0.67 & 1.22 & 0.72 & 1.10 & 0.92 & 2.78 \\
2004 & 1.58 & 2.29 & 0.96 & 0.99 & 1.20 & 0.44 & 1.05 \\
\hline
\end{tabular}

$\mathrm{K}<0.5$ high drought; $0.51-0.69$ drought; 0.70 - 0.99 week drought; $\mathrm{K}>1$ no drought 
Table 4

Proportions of particular species in the composition of lawn mixtures studied in the experiment (own design)

\begin{tabular}{cccc}
\hline Name of mixture & Species & Proportion in $\%$ & Variety \\
\hline \multirow{3}{*}{ M1 } & Festuca rubra & 20 & Adio \\
& Lolium perenne & 20 & Inka \\
& Festuca ovina & 20 & Noni \\
& Festuca heterophylla & 20 & Sawa \\
& Agrostis tenuis & 20 & Niwa \\
\hline \multirow{4}{*}{ M2 } & Festuca rubra & 40 & Adio \\
& Lolium perenne & 15 & Inka \\
& Festuca ovina & 15 & Noni \\
& Festuca heterophylla & 15 & Sawa \\
& Agrostis tenuis & 15 & Niwa \\
\hline & Festuca rubra & 60 & Adio \\
Lolium perenne & 10 & Inka \\
& Festuca ovina & 10 & Noni \\
& Festuca heterophylla & 10 & Sawa \\
& Agrostis tenuis & 10 & Niwa \\
\hline & Festuca rubra & 80 & Adio \\
& Lolium perenne & 5 & Inka \\
& Festuca ovina & 5 & Noni \\
& Festuca heterophylla & 5 & Sawa \\
& Agrostis tenuis & 5 & Niwa \\
\hline
\end{tabular}

The following factors were examined in the monoculture and grass mixture treatments: type of soil substrate with and without the addition of the hydrogel Aqua-Gel P4 (H), type of fertilizer, months of study (V-X), and years of study (2003-2004). In the present experiments, moderately labour intensive lawns (the so-called Relax type) were used.

Nutrients necessary for the proper growth and development of grasses and to guarantee an attractive appearance were provided in two mineral fertilizers: Trawovit (T) (standard fertilizer) and Sierrablen (Sr) (controlled-release fertilizer). Sowing time and rate were determined in accordance with manufacturer's instructions.

At the end of each growing season, samples of turf with the root system were randomly taken from all the plots in three replications. For this purpose, a steel probe (sharpened at the bottom of the cylinder with a diameter of $5 \mathrm{~cm}$ and a length of $15 \mathrm{~cm}$ ) was used; it was hammered down to a depth of 8-10 $\mathrm{cm}$ and then, using a special holder in the upper part of the cylinder, a sample of turf (in the cylinder) was removed from the soil. The samples so collected were subjected to calculations of biomass and live shoots, and subsequently, based on the surface area of the disc, the respective values were converted into an area of $1 \mathrm{~m}^{2}$.

The obtained results were statistically analyzed by performing analysis of variance using an analysis model appropriate for randomized blocks. For major sources of variability (factors and interactions), a detailed comparison was made of the means by $\mathrm{Tu}$ key's test at a significance level of $\mathrm{P} \leq 0.05$.

\section{RESULTS}

The study on monoculture turfs shows that the number of shoots (in no. $\mathrm{m}^{-2}$ ) varied and depended on both red fescue varieties sown and the hydrogel applied. Analysis of variance showed the importance of the interaction between hydrogel and red fescue cultivar. On this basis, it was found that significantly more living shoots per $1 \mathrm{~m}^{2}$ occurred in the plots with the addition of the hydrogel (Table 5). In the mixed lawns, no significant differences were found both between the mixtures and the type of subsoil. For the treatments with and without the addition of Aqua-Gel P4 to the soil substrate, the average number of blades was at a similar level of about 15000 no $\times \mathrm{m}^{-2}$. Favourable weather conditions for the growth and development of grasses in September 2003 contributed the production of a significantly higher number of shoots per unit area compared to the second year. In 2004, about $45 \%$ fewer shoots per $1 \mathrm{~m}^{2}$ was recorded in the monoculture lawns and about $36 \%$ in the lawns with the grass mixtures. The reason for this could be a strong drought which inhibited the growth and development of aerial parts of grasses. Moreover, in the lawns with the red fescue cultivars the number of shoots depended significantly on the hydrogel used in the soil substrate. An increase by about 8.914 shoots per $1 \mathrm{~m}^{2}$, on average for 
the study period, was found in the plots with the contribution of red fescue. In 2003, 6943 fewer grass blades were produced in the monoculture turf plots without Aqua-Gel P4 compared to the treatments where it was used. However, in the year with unfavourable weather conditions (2004) its addition caused a 51\% increase in the number of shoots. Such a beneficial increase in the aboveground parts of the red fescue plants was possible due to the fact that the hydrogel ensured adequate moisture conditions.
Furthermore, in the plots without the addition of the hydrogel, the number of shoots in all monoculture lawns was lower. This study also showed that the number of shoots of the tested cultivars (average for years) also depended on the interaction hydrogel $\mathrm{x}$ fertilizer $\mathrm{x}$ red fescue cultivar (Fig. 1), what allowed us to find that the addition of Aqua Gel -P4 to the soil and fertilization with Trawovit caused a significant increase in the number of shoots in the cultivars Adio, Libano and Corail in relation to the subsoil without hydrogel.

Table 5

The number of shoots (in no $\times \mathrm{m}^{-2}$ ) on average for the studied lawns depending on the hydrogel used and years of study

\begin{tabular}{|c|c|c|c|c|c|c|}
\hline \multirow{3}{*}{ Year } & \multicolumn{6}{|c|}{ Type of lawn } \\
\hline & \multicolumn{3}{|c|}{ Monoculture } & \multicolumn{3}{|c|}{ Mixtures } \\
\hline & $\mathrm{BH}$ & $\mathrm{H}$ & Mean & $\mathrm{BH}$ & $\mathrm{H}$ & Mean \\
\hline 2003 & 25143 & 32086 & 28614 & 18407 & 18598 & 18503 \\
\hline 2004 & 10547 & 21433 & 15990 & 10875 & 12882 & 11879 \\
\hline Mean & 17845 & 26759 & 22302 & 14641 & 15740 & 15191 \\
\hline $\mathrm{LSD}_{0,05}$ & \multicolumn{3}{|c|}{$\begin{array}{l}\text { For years: } 3110 \\
\text { For type of soil substrate: } 3110\end{array}$} & \multicolumn{2}{|c|}{ For years: 3447} & \\
\hline
\end{tabular}

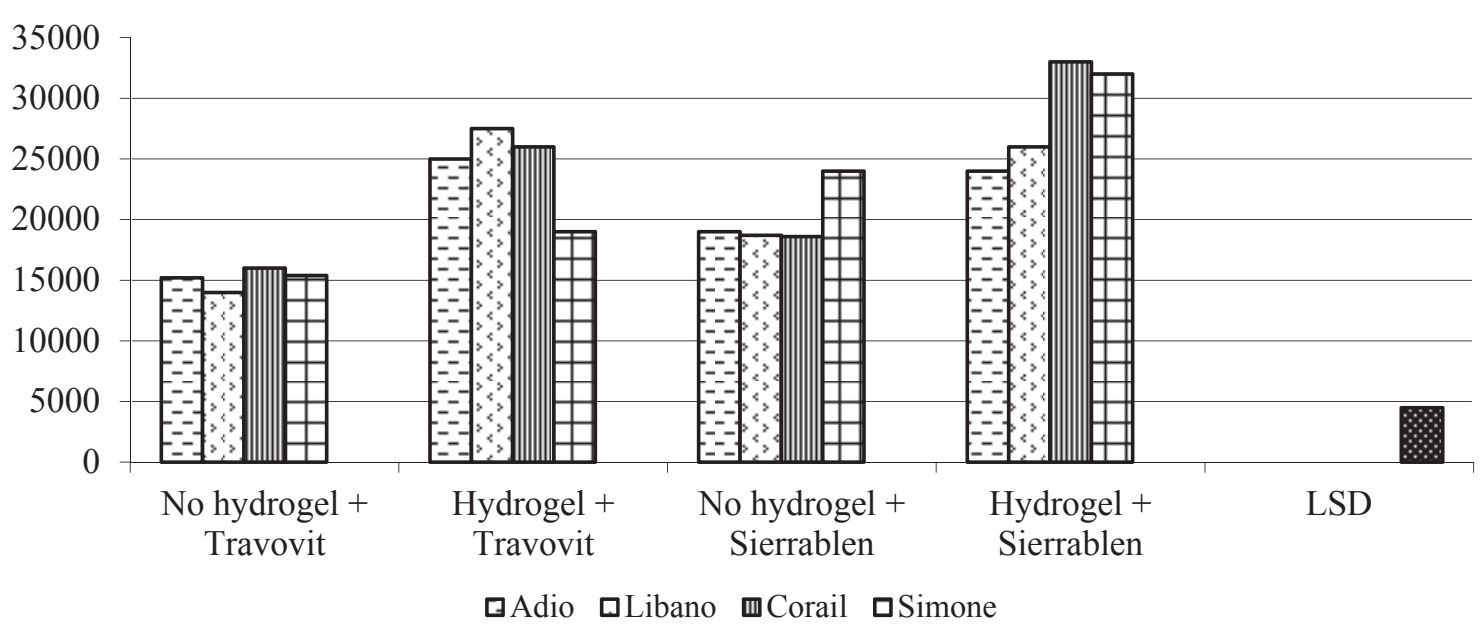

Fig 1. The number of shoots (in no $\times \mathrm{m}^{-2}$ ) for each monoculture lawns depending on the type of soil substrate and fertilizer (average for 2003-2004)

Statistical analysis of the obtained results from the mixed lawns showed a significant effect of the type of mixture on the number of shoots (Table 6). It demonstrates that mainly the species composition of the mixture determines the number of shoots. Significantly, the greatest number of shoots (average for years) was recorded for M1 mixture that contained, in addition to $20 \%$ of red fescue, seeds of the cultivar Adio, up to $20 \%$ of perennial ryegrass (Inka), sheep fescue (Noni), heterophyll fescue (Sawa), brown top grass (Niwa). The significantly lowest number of shoots was obtained on the plots with M2 mixture with a $40 \%$ share of red fescue. These data showed that in the tested mixtures the percentage of red fescue was not the determining factor, but more the other species of lawn grasses. However, the studied monoculture turfs of red fescue cultivars were not statistically different, although the cultivar Corail had the highest number of shoots and the cultivar Adio Polish the smallest one. 
Table 6

The number of shoots (in no $\times \mathrm{m}^{-2}$ ) of different tested cultivars of lawn grasses prepared on the base of red fescue and its mixtures in study years (2003-2004)

\begin{tabular}{|c|c|c|c|c|c|c|c|c|}
\hline \multirow{3}{*}{ Years } & \multicolumn{8}{|c|}{ Type of lawn } \\
\hline & \multicolumn{4}{|c|}{ Monoculture } & \multicolumn{4}{|c|}{ Mixtures } \\
\hline & Adio & Libano & Corail & Simone & M1 & M2 & M3 & M4 \\
\hline 2003 & 26146 & 29872 & 29267 & 29172 & 16649 & 17133 & 17293 & 19936 \\
\hline 2004 & 15445 & 14044 & 18452 & 16019 & 12611 & 11337 & 11719 & 11847 \\
\hline Mean & 20796 & 21958 & 23859 & 22595 & 16130 & 14235 & 14506 & 15891 \\
\hline $\operatorname{LSD}_{0.05}$ & \multicolumn{4}{|c|}{ For monocultures: n.s. } & \multicolumn{4}{|c|}{ For mixtures: 1849} \\
\hline
\end{tabular}

Table 7

The number of shoots (in no $\times \mathrm{m}^{-2}$ ) on average for the studied lawns depending on fertilizers applied during the study period (2003-2004)

\begin{tabular}{|c|c|c|c|c|c|c|}
\hline \multirow{3}{*}{ Years } & \multicolumn{6}{|c|}{ Type of lawn } \\
\hline & \multicolumn{3}{|c|}{ Monoculture } & \multicolumn{3}{|c|}{ Mixtures } \\
\hline & $\mathrm{T}$ & $\mathrm{Sr}$ & Mean for years & $\mathrm{T}$ & $\mathrm{Sr}$ & Mean \\
\hline 2003 & 25907 & 31323 & 28614 & 18582 & 18423 & 18503 \\
\hline 2004 & 14146 & 17834 & 15990 & 10987 & 12770 & 11879 \\
\hline Mean & 20027 & 24578 & 22302 & 14785 & 15597 & 15191 \\
\hline $\mathrm{LSD}_{0.05}$ & \multicolumn{3}{|c|}{ For monocultures: 1352} & \multicolumn{2}{|c|}{ For mixtures: n.s. } & \\
\hline
\end{tabular}

Another factor that determined the higher production of shoots by the tested lawn turfs was the type of fertilizer applied (Table 7). Based on analysis of variance, it was demonstrated that nutrients supplied in the form of the controlled-release fertilizer Sierrablen interact significantly better, with the studied red fescue cultivars producing a greater number of shoots per $1 \mathrm{~m}^{2}$. The varieties produced on average about 4551 live shoots more on the surface where this fertilizer was applied than in the plots where Trawovit was used. In 2003 the lawn grass species used in the mixtures produced a similar number of shoots in the treatments fertilized with both Trawovit and Sierrablen, but in 2004 the mixtures fertilized with Sierrablen produced about 1,783 shoots more than in the plot fertilized with Trawovit, although these differences were not statistically significant.

In view of these results (Fig. 2), the interaction year $\mathrm{x}$ fertilizer $\mathrm{x}$ red fescue cultivar was found to be also important for assessing the number of shoots $\left(\right.$ no $\left.\times \mathrm{m}^{-2}\right)$. The presented results allow one to conclude that in 2003 significantly the highest number of shoots $\left(\right.$ no $\left.\times \mathrm{m}^{-2}\right)$ was noted for the cultivar Simone fertilized with Sierrablen. However, fertilization with Trawovit in the first year of full cultivation gave significantly the highest number of shoots in the plots where the cultivar Adio was sown, while in the second year in the plots with the Corail cultivar. The tested red fescue cultivars, regardless of fertilizer type, developed more shoots in the first year of full cultivation, and among the fertilizers, Sierrablen had a more beneficial effect on this trait than Trawovit.

In the case of mixed lawns (Fig. 3), a greater number of shoots was also obtained in the first year of the study (2003), regardless of the type of fertilizer. Furthermore, the quantity of shoots in the first year was comparable in all mixtures regardless of the type of fertilizer applied. However, in the year 2004 with unfavourable weather conditions for the growth and development of grasses, the controlled-release fertilizer Sierrablen was a better fertilizer.

In turn, the combination of hydrogel and Sierrablen showed that a significantly higher number of shoots was developed by M1 and M4 mixtures. These data show a different response of the tested mixtures to the type of soil substrate and to fertilizers used in the experiment. In the lawns of turf grass mixtures on the base of red fescue, the treatment combinations with hydrogel and fertilizer determined to a lesser extent the development of above-ground parts in the various mixtures. Fertilization with Trawovit, regardless of the addition of the hydrogel, does not lead to a statistical 
difference in the number of shoots between the studied mixtures. A slightly higher number of shoots was obtained after the application of the other fertilizer, Sierrablen, although in both plots, with and without hydrogel, M1 and M4 mixtures had the largest number of shoots. This shows that the percentage of red fescue in the tested mixtures does not determine the number of shoots in a sward, but it is determined more by the type of fertilizer used as well as the addition of hydrogel to the soil substrate.

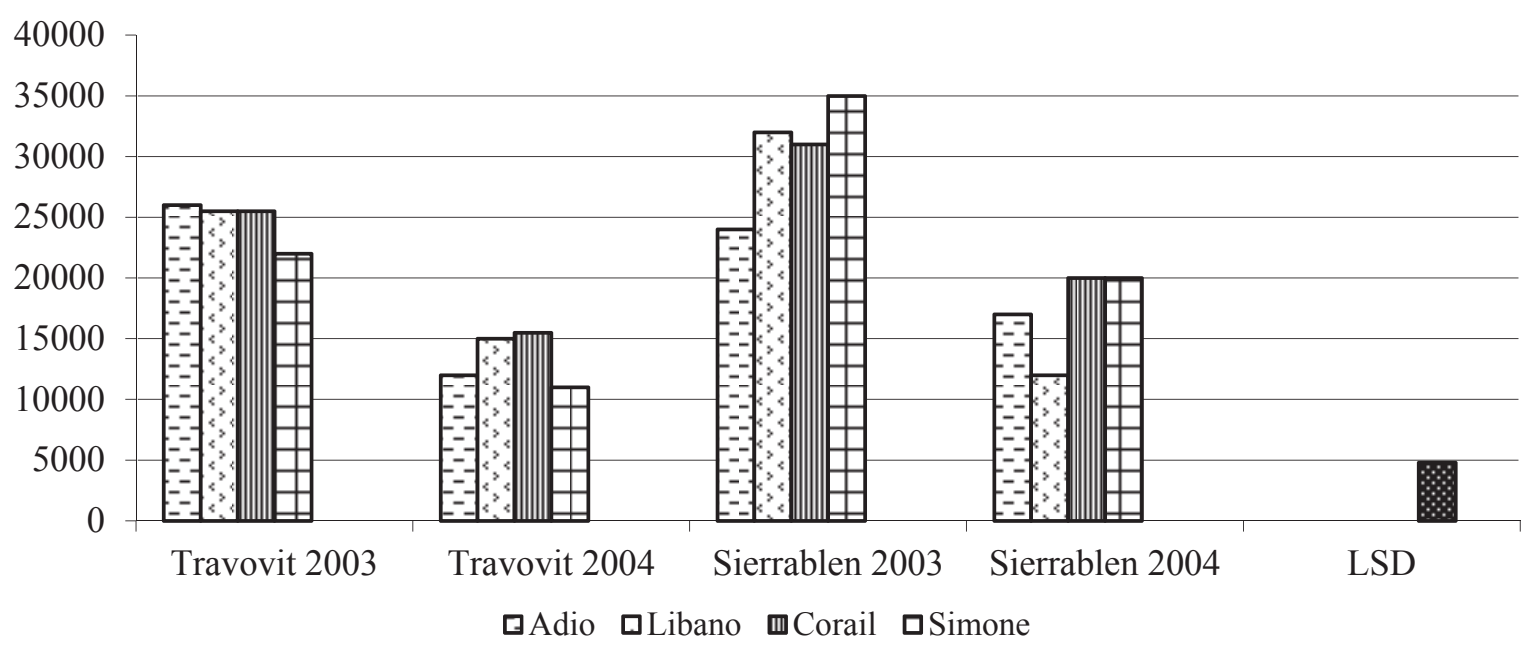

Fig. 2. The number of shoots (in no $\times \mathrm{m}^{-2}$ ) in monoculture lawns, depending on the fertilizers applied in 2003-2004.

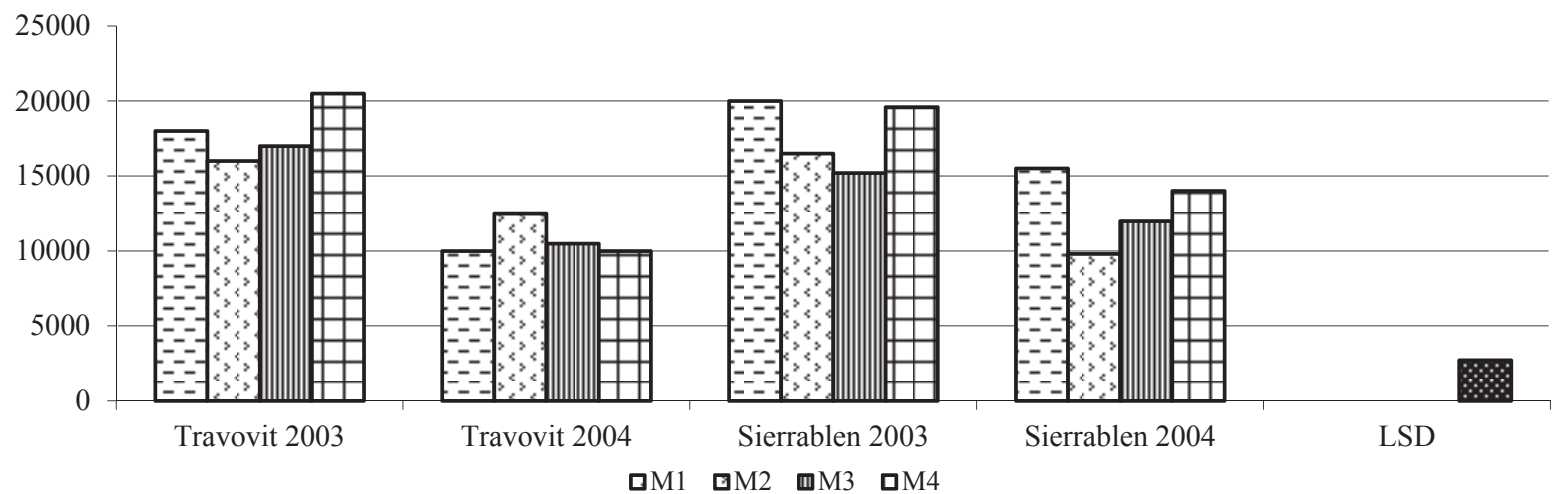

Fig. 3. The number of shoots $\left(\right.$ in no $\times \mathrm{m}^{-2}$ ) in the mixed lawns depending on the fertilizer applied in 2003-2004.

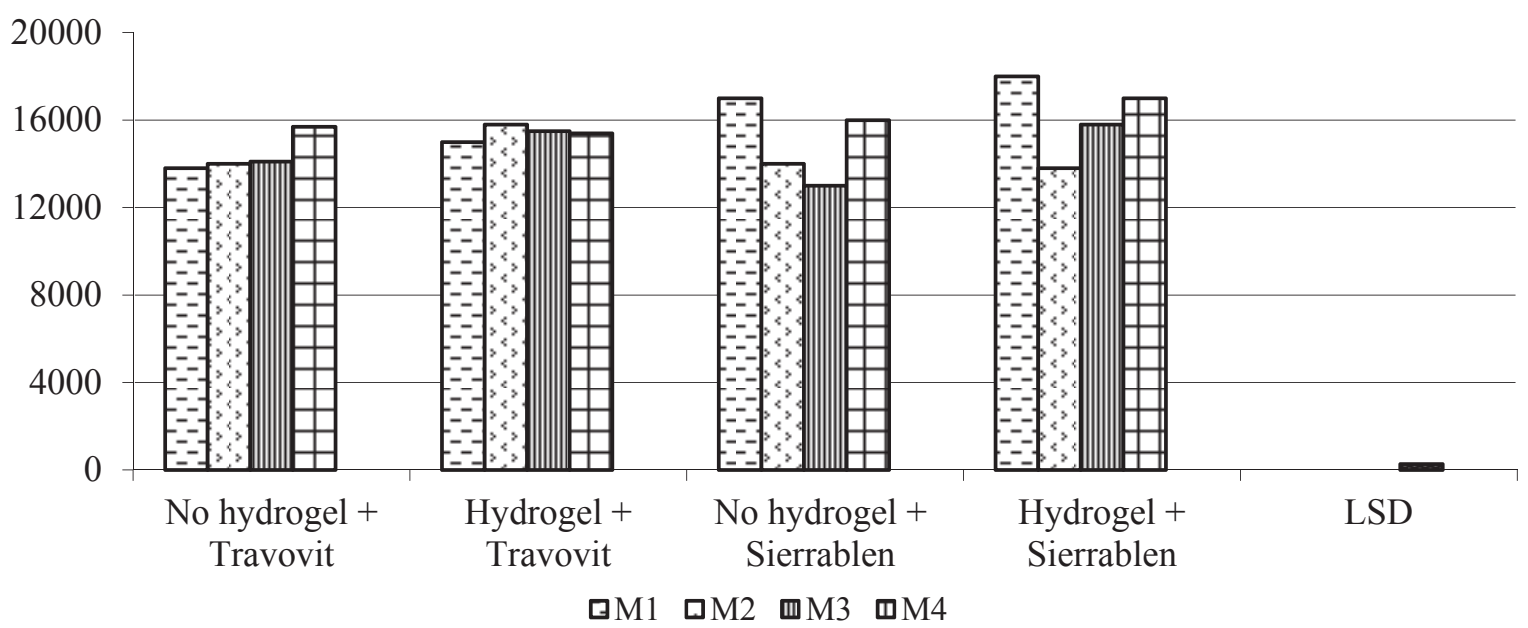

Fig. 4. The number of shoots (in no $\times \mathrm{m}^{-2}$ ) for individual lawn mixtures depending on the type of soil substrate and fertilizer (average for 2003-2004). 


\section{DISCUSSION}

The present study showed that the addition of the hydrogel to the soil caused an increase in the number of shoots of lawn grasses. A particularly significant increase in the number of shoots between the examined soil substrates occurred in the monoculture lawns of red fescue cultivars. The number of shoots in the treatments with hydrogel was almost $50 \%$ higher than in the treatments without hydrogel. A similar effect was obtained by Czeluścińs ki et al. (2006) who found that hydrogel used in the study with perennial ryegrass significantly affected the increase in the number of shoots of evaluated lawn grasses in individual study years. Its activity was more intensive especially in the years when with the most adverse moisture conditions. In a study conducted by Sady and Domagała (1995), hydrogel called Ekogel MI, incorporated into the soil, had a very positive impact on the growth of fresh weight of tested grasses. These results are also confirmed by studies of other authors ( Ge hring and Lew is, 1980; Heli a et al. 1992), showing a definite effect of hydrophilic polymers to improve the conditions of plant growth by stabilizing the soil moisture. $\mathrm{M} \mathrm{i} \mathrm{c} \mathrm{h}$ a lak and Hetman (1997), examining the effect of hydrogel on the growth of seedling rebate plants, showed that the mass of marigold shoots produced in soil with Akrygel was higher by about $38.4 \%$, while for ginseng it was about $29.5 \%$ compared to plants produced without the presence of hydrogel. Analyzing the study factors in their experiments, Kośc i k and $\mathrm{Ko}$ w a l c z y k - J u śk o (1998) found that the number of leaves on the tested plants significantly depended on the interaction of hydrogel and soil conditions.

The cited authors showed that the greatest effect of hydrogel occurred on the lightest soil. According to Gó re c ki and Pa u l, (1993) the most effective use of hydrogel materials was observed on permeable, dry and poor soils.

Regardless of hydrogel treatment, the type of fertilizer used also had an effect on the number of shoots of lawn grasses. The study showed that fertilization of the lawns with the fertilizer Sierrablen had a greater impact on the number of shoots formed than Trawovit. These differences were clearer in the monoculture lawns of red fescue cultivars (approx. 22.7\%) than in the mixtures (about $5.5 \%$ ). The study of $\mathrm{J} \mathrm{an} \mathrm{k} \mathrm{ow} \mathrm{-}$ $\mathrm{s} \mathrm{ki}$ et al. (2011) shows that, from the tested fertilizers, Sierrablen had a favourable impact on colour improvement in monoculture lawns, but in mixed lawns it was Trawovit. It shows varying responses of individual grass species used in the studied mixtures to mineral fertilizers applied.

Given the beneficial effects of hydrogel on the increase in the number of shoots and in view of its beneficial impact under unfavourable moisture conditions, it is advisable to conduct further research into its wider use in lawn cultivation.

\section{CONCLUSIONS}

Due to the differences found in the number of shoots in the studied turf grasses in the study years, it can be concluded that the number of shoots produced by the tested cultivars of red fescue and by its mixtures depended on the meteorological conditions prevailing in each year of full lawn cultivation.

The average number of shoots in the mixtures was about $32 \%$ lower than in the monoculture lawns and it depended on the type of mixture (proportion of red fescue), the cultivar forming a monoculture, and the use of hydrogel in the soil substrate.

The addition of Aqua-Gelu P4 to the soil with Trawovit fertilization resulted in a significant increase in the number of shoots in the cultivars Adio, Libano and Corail in relation to the soil substrate without hydrogel.

Fertilization with Trawovit, regardless of the type of soil substrate, does not lead to a statistically significant difference in the number of shoots between the studied mixtures. However, in the plots fertilized with Sierrablen, the presence of hydrogel in the soil substrate caused a significant increase in the traits examined for the mixtures containing, respectively, 20 and $80 \%$ of red fescue in their composition.

\section{REFERENCES}

Al-Harbi A.R., Al-Omran A.M, Shalaby A., Choudhary M.I., 1999. Efficacy of a hydrophilic polymer declines with time in greenhouse experiments. Hortic. Scie. 34, (2): 223-224.

Bac S., Koźmiński C., Rojek M., 1993. Agrometeorologia. Państwowe Wydawnictwo Naukowe, Warszawa, 32-33.(in Polish)

Czeluściński W., Jankowski K., Jankowska J., Ciepiela G.A., 2006. Wpływ Aqua gel P4 na liczbę źdźbeł oraz plon suchej masy korzeni wybranych mieszanek trawnikowych. / Influence of Aqua -gel P4 on the number of shoots and yield of roots dry matter of some lawn mixtures. Zesz. Nauk. Uniw. Przyrd. Wrocław s. Rolnictwo LXXXVIII: 49 -56.(in Polish)

Domański P., 2002. Gatunki i odmiany traw w mieszankach na trawniki i boiska sportowe. / Species and cultivars of grass in the mixtures on lawns and sports fields. Przegląd naukowy Inżynieria i Kształtowanie Środowiska, 1(24): 83-105.(in Polish)

Gehring J.M., Lewis A.J., 1980. Effect of hydrogel on wilting and moisture stress of bedding plants. Amer-Soc. Hort. Sc. 105(4): 511-513.

Górecki R., Paul M., 1993. Superabsorbenty w ogrodnictwie. / Superabsorbents in horticulture Ogrodnictwo, 4: 12-13. (in Polish) 
Grzebisz W., 2009. Nawożenie roślin uprawnych, tom 2. Nawozy i systemy nawożenia. / Fertilization of crops, Vol 2. Fertilizers and fertilization systems. Wydawnictwo Powszechne Rolnicze i Leśne, 67-112. (in Polish)

Helia A.M., El-Amir S., Shawky M.E., 1992. Effects of Acryhope and Agnastore polymers on water regime and porosity in sandy soil. Int. Agrophysics 6:19-25.

Kitczak T., Czyż H., 2009. Przydatność osadów komunalnych i mieszanek trawnikowych do zadarniania gruntów bezglebowych. / Usefulness of municipal sludge and lawn mixtures in turfing of soilless land. Środowisko - Pomorskie Towarzystwo Naukowe Ochrony Środowiska. 11: 465-471. (in Polish)

Kościk B., Kowalczyk-Juśko A., 1998. Zastosowanie żelu Aqua Terra jako dodatku do podłoża w uprawie tytoniu papierosowego jasnego. / The use of Aqua Terra gel as an additive to the substrate in the cultivation of cigarette light tobacco. Zesz. Prob. Post. Nauk Rol. 461: 227-238. (in Polish)

Kowaliński S., Gonet S., 1999. Materia organiczna gleb. Gleboznawstwo. Wydawnictwo Powszechne Rolnicze i Leśne: 256. (in Polish)

Jankowski K., Jankowska J., Sosnowski J., 2011. Lawn coloring of established on the basis of red fescue, depending on the sorbent applied and the type of fertilizers. Acta Scientiarum Polonorum s. Agriculture. (w druku)

Le ci ej ewski P., 2008. Wpływ wielkości dodatku hydrożelu na zmiany uwilgotnienia i tempa przesychania gleby piaszczystej w warunkach laboratoryjnych. / Effect of the addition of hydrogel on the changes in humidity and the drying rate of sandy soil in laboratory conditions. Studia i Materiały Centrum Edukacji Przyrodniczo-Leśnej. R. 10, 2(18): 316-328. (in Polish)

Martyn W., Onuch-Amborska J., 1998. Ocena tempa wysychania podłoży ogrodniczych w zależności od udziału w nich hydrożelu. / Estimation of the drying rate of horticultural substrates depending on the presence of hydrogel in them. Zesz. Prob. Post. Nauk Rol. 461: 291298. (in Polish)

Martyniak D., 2005. Wpływ ilości wysiewu nasion na obsadę roślin i plonowanie odmian gazonowych kostrzewy czerwonej (Festuca rubra L.) w uprawie na nasiona. / Effect of the amount of seeds sown on plant density and yield of lawn cultivars of red fescue (Festuca rubra L.) cultivated for seed. Biuletyn IHAR 237/238: 259268. (in Polish)

Martyniak D., 2006. Wpływ gęstości siewu nasion na zadarnienie i wygląd trawnika z Festuca rubra L. / Effect of seed density on turfness and appearance of a lawn with Festuca rubra L. Zesz. Nauk. Uniwersytetu Przyrodniczego we Wrocławiu, Rolnictwo LXXXVII, 545: 167-174. (in Polish)

Mellouli H.J., Hartmannb R., Gabriels D., Cornelis W.M., 1998. The use of olive mill effluents as soil conditioner mulch to reduce evaporation lasses. Soil \& Tillage research, 49: 85-91.
Michalak B., Hetman J., 1997. Wpływ hydrożelu na wzrost rozsady i kwitnienie roślin rabatowych. / Impact of hydrogel on the growth of seedlings and flowering of rebate plants. Materiały I Ogólnopolskiej Konferencji Naukowej: Biologia kwitnienia, nektarowania i zapylania roślin. Lublin, 14-15 listopada: 156-162. (in Polish)

Pogroszewska E., 1998. Ocena przydatności Akrylgelu-rp, stosowanego jako komponent podłoża do korzenienia sadzonek skrzydłokwiatu (Spathiphyllum) ex vitro. / Evaluation of the usefulness of Akrylgel-rp used as a substrate component for seedling rooting of Spathiphyllum ex vitro. Zesz. Prob. Post. Nauk Rol. 461: 373386. (in Polish)

Rutkowska B., Hempel A., 1996. Trawniki. Wydawnictwo Powszechne Rolnicze i Leśne, Warszawa: 7-32. (in Polish)

Sady W., Domagała I., 1995. Ekożel MI może być przydatny do zakładania trawników. / Ekożel MI may be useful in establishment of lawns. Ogrodnictwo, I: 2627. (in Polish)

Wolski K., Kotecki A., Spiak Z., Chodek T., Bujak H., 2006. Ocena wstępna możliwości wykorzystania kilkunastu gatunków traw w stabilizacji skarp obwałowań składowiska ,Zielony most” w Rudej. I Preliminary assessment of the possibilities of using several grass species to stabilize of embankment slopes of the landfill "Zielony most" in Ruda. Zesz. Nauk. Uniwersytetu Przyrodniczego we Wrocławiu, Rolnictwo LXXXVII, 545: 294-299. (in Polish)

\section{Wpływ hydrożelu i różnego rodzaju nawozów na liczbę źdźbeł $\mathrm{z}$ darni trawników utworzonych przez monokultury odmian kostrzewy czerwonej (Festuca rubra $\mathbf{L}$.) i jej mieszanek}

\section{Streszczenie}

W badaniach określano wpływ zawartości hydrożelu w podłożu glebowym na liczbę pędów przypadających na jednostkę powierzchni muraw trawnikowych o zróżnicowanym udziale kostrzewy czerwonej. Ponadto w drugim doświadczeniu badano odmiany kostrzewy czerwonej (Adio, Libano, Corail, Simone) wysiane w siewie czystym. W tym celu w latach 2003-2004 przeprowadzono dwa doświadczenia poletkowe w układzie losowanych bloków w czterech powtórzeniach. W kombinacji z hydrożelem (Aqua-Gel P4), sorbent w ilości $0,05{\mathrm{~kg} \times \mathrm{m}^{-2}}^{-2}$ umieszczono na głębokości $10 \mathrm{~cm}$ pod powierzchnią gleby. Kolejnym czynnikiem badawczym był rodzaj nawozu. W tym celu zastosowano Trawovit Komplet (nawóz o standardowym działaniu) oraz Sierrablen (nawóz długo działający). Ilości i termin wysiewu 
nawozu dostosowano do wskazówek producenta. Liczbę źdźbeł przypadającą na $1 \mathrm{~m}^{2}$ powierzchni określono na koniec sezonu wegetacyjnego. Otrzymane wyniki poddano analizie statystycznej, a dla istotnych źródeł zmienności dokonano szczegółowego porównania średnich testem Tukey'a, przy poziomie istotności $p \leq 0,05$. Przeprowadzone badania wykazały, że niezależnie do lat użytkowania, rodzaju podłoża $(\mathrm{H}, \mathrm{BH})$ i nawożenia, średnia liczba pędów trawników mieszankowych była niższa o około $32 \%$ od upraw monokulturowych. Udział hydrożelu w podłożu regulował wilgotność gleby, dlatego też w zasiewach mie- szankowych odnotowano istotnie wyższe wartości badanej cechy na obiektach z hydrożelem. Nawożenie Trawovitem, niezależnie od rodzaju podłoża, nie powodowało statystycznie istotnych różnic w liczbie źdźbeł pomiędzy badanymi mieszankami. Natomiast na obiektach nawożonych Sierrablen, udział hydrożelu w podłożu powodował istotny wzrost badanej cechy dla mieszanek zawierających w swoim składzie 20 i $80 \%$ kostrzewy czerwonej. Dodatek Aqua-Gelu P4 do podłoża przy nawożeniu muraw Trawovitem, spowodował istotny wzrost liczby źdźbeł u odmian Adio, Libano i Corail. 